\title{
Labor paradigms expressed in a model of development and training of personnel for the productive sector
}

\section{Paradigmas laborales expresados en un modelo de desarrollo y capacitación de personal para el sector productivo}

SALINAS-AGUIRRE, María del Consuelo †** HERNÁNDEZ-CUETO, Jaquelina Lizet, YAÑEZFLORES, Sara Margarita and EMILIANO-CASTILLO, Carlos Daniel

Universidad Autónoma de Coahuila, Faculty of Science, Education and Humanities, Research and Postgraduate Department, Building "N" Campus Saltillo, Saltillo Coahuila, Mexico.

ID $1^{\text {st }}$ Author: María del Consuelo, Salinas-Aguirre / ORC ID: 0000-0002-6542-1813, Researcher ID Thomson: S92442018, CVU CONACYT ID: 615635

ID $1^{\text {st }}$ Co-author: Jaquelina Lizet, Hernández-Cueto / ORC ID: 0000-0002-3728-7434, Researcher ID Thomson: S-85882018, CVU CONACYT ID: 322702

ID $2^{\text {nd }}$ Co-author: Sara Margarita, Yañez-Flores / ORC ID: 0000-0002-4750-4244, Researcher ID Thomson: S-92312018, CVU CONACYT ID: 352125

ID $3^{\text {rd }}$ Co-author: Carlos Daniel, Emiliano-Castillo / CVU CONACYT ID: 1095096

\begin{abstract}
Based on the results of an investigation "Alternatives of human development with labor qualification", attributes are extracted as inputs that the workers indicate as important in: job performance, training, human development and job reality expressed in task variability, job identity, importance of work, autonomy of functions and performance feedback. Integrated results reflect an innovative development and training scheme based on worker needs parallel to personnel administration. The integrated results reflect an innovative development and training scheme based on worker needs parallel to personnel management. Personnel development has four levels: 1st Strategic planning of work development. In this part, the organization reviews: job profiles, recruitment and selection techniques; 2nd Diagnosis of training and development needs: the employee's trajectory is evaluated from: induction, interview to visualize the worker's expectations, skills, attitudes and experience, a personalized business career design is built; 3rd Development and job training with an apprenticeship program: application in three strata: staff who make managerial decisions; employees of administrative, management and logistics services; line operators and maintenance services; 4th Context, work processes and aspects of the employee's personality, experience, work climate, type of work and level of command, nature of the work, highperformance collaborative tasks, operations management, production, technologies, etc.
\end{abstract}

Staff training
Resumen

En base a resultados de una investigación "Alternativas del desarrollo humano con habilitación laboral", los trabajadores señalan atributos importantes del desempeño laboral, capacitación, desarrollo humano y realidad laboral expresada en variabilidad de tareas, identidad laboral, importancia del trabajo, autonomía de funciones y retroalimentación del desempeño. Los resultados integrados reflejan un esquema innovador de desarrollo y capacitación basado en necesidades del trabajador paralelo a la administración de personal. Desarrollo de personal tiene cuatro niveles: $1^{\circ}$ Planeación estratégica del desarrollo laboral. En ésta parte, se revisan en la organización: perfiles de puestos, técnicas de reclutamiento y selección; $2^{\circ}$ Evaluación y diagnóstico de necesidades de capacitación y desarrollo: de la trayectoria del empleado desde: inducción, entrevista para visualizar expectativas, habilidades, actitudes y experiencia del trabajador, se construye un diseño de carrera empresarial personalizado; $3^{\circ}$ Desarrollo y capacitación laboral con un programa de aprendizaje: aplicación en tres estratos: el personal que toma decisiones directivas; empleados de servicios administrativos, de gestión y logística; operarios de línea y servicios de mantenimiento; $4^{\circ}$ Contexto, procesos laborales y aspectos de personalidad del empleado, experiencia, clima laboral, tipo de trabajo y nivel de mando, naturaleza del trabajo, tareas colaborativas de alto rendimiento, administración de operaciones, producción, tecnologías, etc.

Modelo capacitación de personal

Citation: SALINAS-AGUIRRE, María del Consuelo, HERNÁNDEZ-CUETO, Jaquelina Lizet, YAÑEZ-FLORES, Sara Margarita and EMILIANO-CASTILLO, Carlos Daniel. Labor paradigms expressed in a model of development and training of personnel for the productive sector. Journal of Human Resources Training. 2020. 6-17:28-33.

\footnotetext{
* Author's Correspondence (Email: consuelo.salinas@uadec.edu.mx)

$\dagger$ Researcher contributing as first author.
} 


\section{Introduction}

In "The structure of scientific evolutions" by Thomas Kuhn (1962), the paradigm concept was born, as "subjective lenses", which give a perspective of support to theories, ideas, concepts and thoughts expressed in models that reflect the reality of current scientific communities, which contributes to science with truths recognized as universal at a certain historical moment. Today, a paradigm is described, as a partial way of seeing the world, which simultaneously hides and prevents the perception of other qualities, Urzúa (2016). It becomes a Paradigm of Complexity with Morín (2000), he says, a paradigm is restricted when the disciplinary vision is particular and becomes generalized, by including multiple interdisciplinary or transdisciplinary perspectives.

The generalized complex paradigm of the proposal is to innovate the development of people, with an approach focused on the opinions that the worker claims to need, in addition to having a multidisciplinary perspective from pedagogy, personnel management, industrial psychology and total quality at work.

It is urgent to reinvent and change theories of personnel management to train and develop human resources in a diverse way, as an adaptation "a priori" and necessary to these drastic changes in the way of life that include reinvented business work, from environments virtual and with unthinkable ways of working, socializing, producing, marketing, etc. in the past.

An innovative model is proposed parallel to the administration of personnel to train and develop workers according to a diagnosis of needs expressed in an investigation of "Alternatives for human development with employment qualification" Salinas M.C. (2015). These results enriched with a non-experimental field research with opinion surveys of university workers and work experience of the researcher in the UAdeC's Senior Rectory Office for 10 years, where a Manual of the organization, job analysis and evaluation was carried out to job performance, these tools are constituted for implementation in a university staff database system (designed in Java language).
The methodological scheme of the staff development model is parallel and integrated to the functions of the human factor within organizations.

The methodology directly linked to the work processes is transformed into the "know how" for the development of people within the company according to the profile and work needs. An added value is presented when the worker's needs are satisfied, this translates directly into motivation and satisfaction at work, which results in optimal performance reflected in the quality of the product and service provided to consumers.

The interdisciplinarity and multidisciplinary educational work approach forms an amalgam of scientific disciplines that they intend to develop from a humanistic perspective, various authors contribute from 1991 to 2009, among them: Schultz D.P .; Martínez Izaguirre R .; Werther Werther W.B. and Davis K .; Hodgetts R. M. and Altman S. and Pérez S. U.

\section{Methodology to be developed}

The etiology of this training model for companies is, on the one hand, the research "Alternatives for human development with labor qualification" Salinas M.C. (2015), with a nonexperimental, quantitative design, with a vertical cross-section, when collecting the data from a sample, a piloted instrument with a Crombach Alpha of 0.92 is applied, the measurement of 6 signal variables to characterize the random sample of 210 subjects. employees in three public agencies (one is university), the questionnaire of nominal variables are grouped into three complex axes: personnel training, development needs at work and context and work environment, this last axis is based on studies of organizational behavior on constant variables from the work of Hodgetts RM and Altman S. The statistical treatment of descriptive analysis data is carried out with percentages and readings of means and indicators of central tendency. The correlational study is with Pearson and the multivariate one using the factorial method, the first 5 factors are analyzed with an explanation of $68 \%$ of the phenomenon, the first factor that refers to human attributes that matter to workers such as self-realization, but through transcending in social aspects, it presents a variance of 32.64 is the one with the highest eigenvalue.

SALINAS-AGUIRRE, María del Consuelo, HERNÁNDEZ-CUETO, Jaquelina Lizet, YAÑEZ-FLORES, Sara Margarita and EMILIANOCASTILLO, Carlos Daniel. Labor paradigms expressed in a model of development and training of personnel for the productive sector. Journal of Human Resources Training. 2020 
In addition to this research, an investigation carried out to the staff of the Autonomous University of Coahuila is taken as a basis, for the preparation of the Organization Manual with job profiles and another for Performance Evaluation that were the input of a computer system of human resources, prepared for the data administration of the Autonomous University of Coahuila, in the Mayor's Office of the Rectory (2000).

These two investigations integrated into the work experience acquired in personnel administration in the Subdirectorate of Senior Officials Office of the UAdeC, resulted in a model of personnel development and training based on the real needs of the workers of the university institution.

\section{Results}

The change from a traditional and obsolete paradigm of "safe work" with expectations of earning a living, conforming and suffering a job to maintain a hard life where the important thing is to meet the objectives to give economic results, accepting any opportunity with the philosophy " the end justifies the means" by Machiavelli, where you have to study and strive hard to control, anticipate and anticipate any setback and meet strategically planned short, medium and long-term goals. The current paradigm is one of dynamic and sustainable work with ecological perspectives, where independent professionals are rewarded, innovation and betting, visualizing, invoking and creating a dream, crystallizing changes with talents and service to others, the purposes are enjoyed and compromised. of persevering, flowing, collaborating, choosing constant and personal renewal, connecting and introjecting natural values in favor of the conservation of humanity.

The results of the descriptive analysis of the research "Alternatives of human development with work authorization" show workers that $64 \%$ have morning shifts, $21 \%$ evening shifts and $15 \%$ mixed; $78 \%$ are women, the rest are men in an age range between 18 to 78 years, the functions in most correspond to middle positions, which include office, service, supervision and management jobs.
In the correlational and factorial analysis, personal aspects stand out in the foreground, as significant (with an $r$ squared of 0.25 ), the variables of the axis "development needs at work", especially those of individual development. Second, culturally learned variables were found of importance for the workers, such as needs in personal development such as: giving results, orienting oneself to serve society, greater personal value is given to jobs related to jobs that involve reasoning functions, activities of the front and left part of the cerebral cortex such as; thinking, understanding and problem solving. In a second level of importance, the workers surveyed importance at work to tasks of the position linked to social and cultural learning such as prestige, hierarchies of command power, social status, responsibilities and obligations that imply dissemination, authority and social reputation before the community that they live.

What is relevant found in the field research carried out with a questionnaire to analyze and shape the university's job profiles is: $63 \%$ of workers give priority to relationships with peers over work, $76 \%$ opt for tasks in collaboration with peers, $56 \%$ prefer managerial and decision-making positions, $92 \%$ privilege people with studies, $54 \%$ do not like physical tasks, $27 \%$ feel they are less in maintenance and cleaning positions, $34 \%$ prefer to have work in other parties, $86 \%$ like parties and social gatherings, $82 \%$ are obedient to the boss's orders, $32 \%$ have more than one boss simultaneously, $22 \%$ are engaged in research, and $60 \%$ are bosses and $40 \%$ subordinates, for which the decision-making hierarchy is invested according to administrative theories, $89 \%$ are hired by acquaintances or relatives. 


\section{Annexes}

\section{Paradigm in the training model}

\section{Staff development and training paradigms}

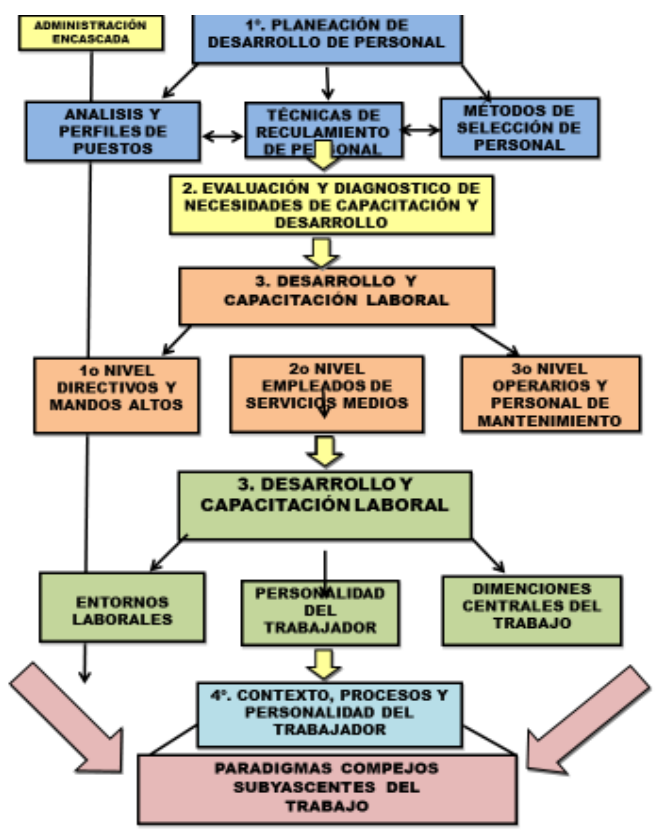

\section{Acknowledgments}

To the UAdeC staff who collaborated in supporting the application and answering of the investigations and to the directors for supporting personnel investigations.

\section{Conclusions}

The training model within the strategic administration of the institution has four levels or consecutive stages:

1st Strategic planning of work development. This part refers to the preparatory actions prior to establishing a career plan for the worker within the company. In this part, they are reviewed in the organization:

1.1. Analysis and job profiles. Investigate and document all job positions, delimiting key and auxiliary functions, as well as requirements to fill the position. The parts of the job function analysis are: 1.1.1. Identification of the worker with her generals. 1.1.2. Generic job description: it stipulates in summary the main function of the job position. 1.1.3. Job Specific Description: Critical actions required that are repeated to achieve job results.
1.1.4. Eventual description of the position: eventual tasks, which complement the work activities of that specific position. 1.1.5. Requirements of the position: studies, special knowledge or physical skills and previous experience essential to occupy the job.

1.2. Recruitment techniques. Apply the methods according to the required personnel and the potential to develop of possible candidates.

1.3. Personnel selection methods. Carry out the possible candidate: documentation, interviews and evaluation of experiences, vocation, knowledge, abilities, previous expectations, aptitudes, needs, opportunities to be trained, necessary psychometric and psychological studies.

2nd Assessment and diagnosis of training and development needs. Detection of opportunities from recruitment, selection, hiring, induction, specific evaluations for the position, interview of the candidate by the personnel department, an analysis of the candidate's trajectory will be carried out to prospect a future projection, such as development plan and permanence within of the organization. Expectations, motivations, experience are taken into consideration for the business career design.

3rd Development and job training. Carrying out a pedagogical intervention program with personalized learning programs with an application in three strata: 3.1. Level. Personnel who make senior management decisions. 3.2. Level. Middle service employees in job hierarchies, with administrative functions, management of resources / processes and operational logistics of the work. 3.3. Level. Production line operators and property cleaning and repair services.

$4^{\text {th }}$ Context, work processes and aspects of the employee's personality. The climate or work environment, in two aspects: 
4.1. Environmental aspects of the environment: operational processes, nature of work, type of product or service, line of business, clients and suppliers, leadership styles, task logistics, labor administration systems, regulations of the collective bargaining agreement, hierarchical level of command, socioeconomic level of origin, public policies applicable to the institution or business, use of information and automation technologies, training and enrichment of the job, breadth and density of tasks, performance evaluation, system of rewards and incentives for staff, feedback performance, industrial safety, job stability, wage and salary system, medical care, occupational hygiene and ergonomic facilities appropriate to the type of work and quality of working life. 4.2. Worker personality, which includes: person and behavior style, skills, competencies, personal previous experiences, individual needs and expectations, collaborative attitudes, motivation towards work, job satisfaction, work and family affective relationships, conduct disorders, illnesses professionals, identification with the position, personal motivations, professional vocation, resilience and adaptation to changes, selfrealization at work, initiative, creativity, autonomy, health and lifestyle.

To complement the work, consider in this new complex paradigm the strategic planning of the organization in terms of mission, vision and to implement the model, take into consideration the 4.3. Central dimensions of work. 4.3.1 Variety and enrichment at work, integrate the diversity of tasks into the job functions, as well as take care of the quality and density of workloads. 4.3.2. Identity with work, promoting emotional aspects of identification and attachment to the organization in workers. Implement meaning to work and recognize the importance of personal prestige and social status of work activities. 4.3.3. Autonomy of the worker, to allow innovation and creativity in work functions outside of what is already systematized and programmed at work. 4.3.4. Feedback, give performance evaluation results as areas of opportunity for development and necessary training courses, Hackman J. R. and Oldham G. R. (2005)

\section{References}

Arias Galicia F. (2000). Editorial Trillas, Administración de Recursos Humanos.

Chruden H. y Sherman A. (2001). Administración de Personal. Maximización del Potencial de Empleados. CECSA.

Constitución de los Estados Unidos Mexicanos. (1917). artículo 123 (reforma 2012).

Hodgetts R. M. y Altman S. (2005). Comportamiento en las Organizaciones. Mc Graw-Hill. México.

Davis K., Mc Graw-Hill. (2006). Comportamiento Humano en el Trabajo. Editorial Mc Graw-Hill. México.

González Alanís A.H. Apuntes y didactemas decorado y postdoctorado (2018).

Kuhn T.S. (2010). Traduccion Solís Santos C. Primera edición electrónica The Sructure of Scientific Revolutions. The Unvesity of Chicago Press (1970). Www,fondode culturaeconomica.com

María-José dunjó (2020). Reinvención profesional. Artículo 25. Editorial Amat.

Mcfarland D. E. (2002). Administración de Personal. Editorial Fondo de la Cultura Económica. México.

Robbins S. (2006), Comportamiento Organizacional. Self-Assessment Library. (original Editorial Mc Graw-Hill). México.

Salinas M.C. (2013). Tesis Habilitación Laboral Ph D. UAdeC. México.

Sánchez-Cerezo J. (2003). El pensamiento de T.S. Kuhn. Artículo publicado en webdianoja.

Schultz D.P. (2004). Psicología Industrial. Editorial Mc Graw-Hill. México.

Trueba Urbina A. y Trueba Barrera J. (1988). Ley Federal del Trabajo: comentarios, prontuario, jurisprudencia y biografía. Capítulo. Teoría Integral del Derecho del Trabajo.http://ri.uaemex.mx/handle/20.500.117 99/84510http://ri.uaemex.mx/handle/20.500.11 $799 / 84510$. 
Ubaldo Pérez S. y Martínez Izaguirre R. (2009). Modelo Andrológico Fundamentos, UVMLaureate.

https://www.bibliotecas.uvmnet.edu/portico/doc /libros/AndragogiaFundamentos.pdf

Werther W.B. y Davis Keith. (2008). Administración de Recursos Humanos Editorial Mc Graw-Hill. México.

https://www.academia.edu/13281568/Administr acion_de_Personal_y_Recursos_Humanos_Wil liam_b_Werther_6ta_Edicion_PDF_1 